1 Outcome measures used in psoriatic arthritis registries and cohorts: a 2 systematic literature review of 27 registries or 16,183 patients

3

4 Running title: Outcome measures in PsA registries 5

Word count (abstract): 283

Word count (manuscript): 2,782 Laure Gossec ${ }^{1,4}$ Paris, France.

2 Saint-Joseph University, Faculty of medicine, Beirut, Lebanon.

3 Antananarivo Faculty of medicine, Antananarivo, Madagascar. de Santé Publique, Paris, France.

\section{Corresponding author for submission:}

Dr. Krystel Aouad l'Hôpital - 75013, Paris, France

krystel.aouad@hotmail.com

ORCID ID: https://orcid.org/0000-0001-8708-9324

Corresponding author for reprints: Prof. Laure Gossec l'Hôpital - 75013, Paris, France

ORCID https://orcid.org/0000-0002-4528-310X

Krystel Aouad $^{1,2}$, Georgia Moysidou ${ }^{1}$, Antsa Rakotozafiarison ${ }^{1,3}$, Bruno Fautrel ${ }^{1,4}$,

1 Rheumatology department, AP-HP Sorbonne Université, Pitié-Salpêtrière hospital,

4 Sorbonne Université, INSERM UMRS 1136, Institut Pierre Louis d'Epidémiologie et

AP-HP, Pitié-Salpêtrière hospital, Rheumatology department, 47-83, boulevard de

AP-HP, Pitié-Salpêtrière hospital, Rheumatology department, 47-83, boulevard de

laure.gossec@aphp.fr Tel: +33142178421Ｆax: +33142177959 


\section{Introduction}

4 Psoriatic arthritis (PsA) is a multidimensional inflammatory disease for which multiple

\section{ABSTRACT}

outcome measures can be used to assess disease activity. In 2006, the OMERACT has proposed the first core domain set in PsA. Since 2006, much work has been performed on outcome measures in PsA.

\section{Objectives}

The purpose of this study was to assess outcome measures collected in recent PsA registries or longitudinal cohorts.

\section{Methods}

A systematic literature review was performed in Pubmed Medline (PROSPERO CRD42020175745) to identify all articles reporting on either registries or longitudinal cohorts in PsA, published between 2010 and March 2020. Registries centered on drugs or not PsA-specific, trials and long-term extension studies were excluded. The data collection comprised patient characteristics and the clinical outcome measures reported, including composite scores and patient reported outcomes (PROs). Statistics were descriptive.

\section{Results}

Of 673 articles, 73 were analysed, reporting on 27 registries/cohorts. Overall, 16,183 patients were included, with a mean of 599 per study; $51 \%$ were men, weighted mean age was $49.7 \pm 9.3$ years and weighted mean disease duration was $6.8 \pm 0.2$ years. Overall, 58 different outcome measures were collected. Disease activity composite scores were used in 20/27 (74\%) registries through 8 different scores (most frequently Minimal Disease Activity: 41\%, DAS28: 33\% and DAPSA: 30\%). Among the domains of PsA, joint involvement was reported in 26/27 (96\%) registries (through the 66/68 joint count: $85 \%$ ) and skin psoriasis in 93\% (through PASI: $72 \%$ ), whereas enthesitis, dactylitis and axial involvement were less often reported (respectively, 77\%, 74\% and $52 \%)$. Furthermore, 22/27 (82\%) studies reported HAQ; the other frequently reported PROs were patient global assessment (70\%) and pain (63\%).

\section{Conclusions}

Data collection in PsA is very heterogeneous, reflecting the need for international consensus on outcome measures.

Keywords: outcome measures; psoriatic arthritis; registries; cohorts. 


\section{INTRODUCTION}

2 Psoriatic arthritis (PsA) is a heterogeneous and multidimensional inflammatory disease

3 with variable manifestations and progression.(1-3) Numerous outcome measures can

4 be used in PsA, some are specific to PsA such as Minimal Disease activity (MDA),

5 some are generic such as patient assessment of pain and some are borrowed from

6 rheumatoid arthritis (RA) such as the Disease Activity Score (DAS28).(2,4-6) There is

7 no consensus on the optimal instruments to measure disease activity and evaluate

8 treatment response in PsA. $(7,8)$ We previously reported a lack of uniformity in PsA

9 evaluation of disease activity in randomised controlled trials (RCTs) in 2012.(9) In 58

10 clinical trials reviewed, 84 different outcome measures were used.(9)

11 In 2016, an updated PsA core set of domains to be assessed in all RCTs and

12 longitudinal observational studies (LOS) was proposed by the Group for Research and

13 Assessment of Psoriasis and Psoriatic Arthritis (GRAPPA) and Outcome Measures in

14 Rheumatology (OMERACT).(10,11) Eight inner core set domains are recommended

15 to be assessed systematically in every RCT and LOS and include: musculoskeletal

16 disease activity (peripheral joints, dactylitis, enthesitis, and axial involvement), skin

17 disease activity, systemic inflammation and 5 patient reported outcomes (PROs):

18 fatigue, pain, patient's global assessment, physical function, and health-related quality

19 of life.(11) Furthermore, several other domains are proposed in the core set as

20 important (but not mandatory) domains.(11)

21 Although the core set lists domains to be assessed in PsA, there is currently no

22 consensus on the best outcome measures to use. $(11,12)$

23 Another important aspect relates to composite scores. The treatment target in PsA is 24 remission or alternatively low disease activity (LDA); $(7,8)$ several composite scores 
1 allow the assessment of remission or LDA in PsA, without a current agreement on a

2 single score.(13-17)

3 Registries may provide important insights into the outcomes collected in PsA. By

4 definition, patient registries use "observational study methods to collect uniform data

5 (clinical and other) to evaluate specified outcomes for a population".(18) Exploring

6 outcome measures collected in recently published registries or longitudinal cohorts

7 may provide a photograph of current clinical practices.(19)

8 The objective of this study was to assess outcome measures collected in ongoing PsA

9 registries or longitudinal cohorts, through a systematic literature review.

\section{MATERIAL AND METHODS}

12 This systematic review was conducted according to Cochrane guidelines.(20) The 13 protocol was registered on PROSPERO (CRD42020175745).(21)

\subsection{Search and selection strategy}

The search included all publications of cohorts or registries reporting any clinical data in PsA published between March 1, 2010 and March 1, 2020. We searched the

17 electronic database PubMed MEDLINE using the terms "Arthritis, Psoriatic"[Mesh] AND ("Registries"[Mesh] OR "Cohort Studies"[Mesh]). Although an EMBASE search was initially planned, we only performed the search in PubMed due to limited added value of EMBASE.(22) Publications concerning the same registry were analysed

21 together, publication used for demographic characteristics was the last published or the one with the most patients. Three authors (KA, GM, and AR) independently

23 scanned the title, abstract and keywords of every record identified. In the event of 24 disagreement between the reviewers, disparities were discussed and resolved. If 
1 needed, the registry correspondent was contacted and registries websites were 2 consulted.

\section{$4 \quad 2.2$ Inclusion criteria and participants}

5 Patients were adults with a confirmed diagnosis of PsA (using Classification Criteria 6 for Psoriatic Arthritis (CASPAR) or Moll and Wright criteria or according to the

7 physician's diagnosis). Registries or cohorts reporting at least one clinical outcome and 8 including at least 50 patients with PsA were selected. All the registries or cohorts 9 included patients with PsA, and some included patients with psoriasis and/or 10 spondyloarthritis.

\subsection{Exclusion criteria}

13 All biologic registries, registries centered on treatments or registries for health care 14 products, and post-marketing surveillance were excluded because they were not 15 specific to PsA, and thus did not reflect PsA-specific outcome measures. Papers not 16 reporting any clinical outcome measures (e.g., articles reporting only laboratory 17 outcomes, radiographic scores, or genetic analyses) were excluded. RCTs and long18 term extensions, retrospective and cross-sectional studies, case series, reviews, and 19 editorials were excluded.

\subsection{Data extraction}

22 The authors extracted relevant data from the included articles into a pre-defined case 23 report form (CRF). Only published outcomes measures were collected and analyzed. 
1 General data extraction Descriptive data were extracted on the type of study

2 (international, nationwide or local) and patients' characteristics.

3 Clinical outcomes The outcome measures assessing the GRAPPA/OMERACT inner

4 core domain set were collected.(11) These include musculoskeletal disease activity

5 (peripheral joints, enthesitis, dactylitis, spine symptoms), skin disease activity, pain,

6 patient's global assessment, physical function, Health-related quality of life (HRQoL),

7 fatigue and systemic inflammation.(11) All the outcome measures relevant to these

8 domains were collected. Physical function measures were the $H A Q$, modified $H A Q$ and

9 Bath Ankylosing Spondylitis Functional Index (BASFI). Spine symptoms were assessed through the Bath Ankylosing Spondylitis Functional Disease Activity Index

11 (BASDAI), or through a binary score (yes/no) and/or. Skin disease activity was assessed through Psoriasis Area Severity Index (PASI) and/or Body Surface Area 13 (BSA).

Health-related quality of life (HRQoL) was assessed through the 36-Item Short Form Survey (SF-36), Short-Form 12 (SF-12), Dermatology life Quality Index (DLQI), EuroQol 5 domain (EQ-5D), Psoriatic Arthritis Quality of Life (PsAQoL) and/or Ankylosing spondylitis quality of life score(ASQoL).(5,13,17,23,24)

Then, we collected the domains considered important in the core set, i.e., economic cost, emotional well-being, participation (work, leisure and social activities) and structural damage. Finally, other outcomes of importance to patients and included in

21 the OMERACT research agenda, were collected, i.e., independence, sleep, stiffness 22 and treatment burden.(11) Physician global assessment was also collected.

23 Composite scores were collected: MDA, Very Low Disease Activity (VLDA), Disease 24 Activity Index for Psoriatic Arthritis (DAPSA), Composite Psoriatic Disease Activity 
1 Index (CPDAl), Psoriatic Arthritis Response Criteria (PsARC), Psoriatic Arthritis

2 Disease Activity Score (PASDAS), Disease Activity Score (DAS28 CRP/EULAR

3 response), and ACR response, and Arithmetic Mean of the Desirability Function

4 (AMDF). $(5,13,17,23,24)$

\section{$5 \quad 2.5$ Statistical analysis}

6 A quantitative summary of findings was performed including frequencies of each

7 outcome. Risk of bias was not assessed because we were exploring outcomes

8 collected not results of outcomes. The frequency of reporting of domains in

9 cohorts/registries which had started the data collection before versus after 2007 (date

10 of publication of the first OMERACT core set) (10) was compared by the chi-square

11 test with Yates' correction.(10) Meta-analysis was not undertaken. 


\section{RESULTS}

\subsection{Description of PsA registries/cohorts publications}

4 Of 673 articles, 73 were relevant for analysis, reporting on to 27 PsA-specific registries

5 or cohorts (Figure 1 and Supplementary table S1). The characteristics of the

6 registries, PsA-specific cohorts and patients evaluated are shown in Table 1. The total

7 number of patients was 16,183 with a mean of 599 per study. Overall, 8,224/16,183

$8(50.8 \%)$ were men, weighted-mean age was $49.7 \pm 9.3$ years and weighted-mean

9 disease duration was $6.8 \pm 0.2$ years. Most of the registries were established in Europe

$10(18 / 27,66.7 \%)$ or North America $(7 / 27,25.9 \%)$ and 12/27 (44.4\%) included patients

11 from a single center. Overall, 21/27 (77.8\%) applied the CASPAR criteria,(25) and the 12 same number reported treatments.

\section{$13 \quad 3.2$ Composite scores}

14 Overall, 58 different clinical outcome measures were collected. Disease activity 15 composite scores were reported in 17/27 (63.0\%) registries: of these, $11 / 27$ (40.7\% of 16 all registries) reported MDA, 9/27 (33.3\%) DAS28 and 8/27 (29.6\%) DAPSA; whereas 17 PSARC and PASDAS were reported each in only $7.4 \%$ of the studies. VLDA and AMDF 18 were never reported (Figure 2).

\subsection{PsA inner core set domains}

20 Eleven registries/cohorts collected all of the 2006 core set domains and only 2 21 registries/cohorts reported all of the 2016 updated 8 core set domains. The inner core 22 set domains were reported variably between $33.3 \%$ and $96.3 \%$ (Table 2). Joint 23 involvement was reported in $26 / 27$ (96.3\%) using variable joint counts, most frequently 
1 the $66 / 68$ joint count (in 20/23, $87.0 \%$ studies). Damaged joint count was less

2 frequently reported $(7 / 27,25.9 \%)$.

3 Skin psoriasis was reported in 25/27 (92.6\%) registries, most frequently through PASI

4 in 18/27 (66.7\%), and BSA in 12/27 (44.4\%). Enthesitis was reported in 21/27 (77.8\%)

5 registries, using most frequently Leeds Enthesitis Index (33.3\%) and/or Maastricht

6 Ankylosing Spondylitis Enthesis Score (MASES) (23.8\%), whereas dactylitis was less

7 often reported $(20 / 27,74.1 \%)$, using mainly the number of digits $(40.7 \%)$. Axial

8 involvement was reported in 15/27 (55.6\%) through clinical binary assessment (yes/no)

9 (14/27, 51.9\%) and/or BASDAI (9/27, 33.3\%). Systemic inflammation was evaluated 10 mostly through CRP (90.4\%).

11 Overall, 22/27 (81.5\%) of the registries reported HAQ, and the other frequently 12 reported PROs were patient global assessment (70.4\%) and pain (63.0\%). HRQoL 13 was collected in 15/27 (55.6\%) using mainly the SF-36 (46.7\%), EuroQol-5 (46.7\%), 14 and DLQI (46.7\%). Fatigue was the least frequently reported core set domain, collected 15 in 9/27 (33.3\%) studies (Figure 2 and Table 2).

\subsection{Other domains reported}

Among the domains considered as important by GRAPPA/OMERACT,(10) structural damage was the most frequently reported (10/27, 37.0\%), and was evaluated through X-rays in 9/10 (90\%) cases. Emotional well-being and participation were reported in $11.1 \%$ and $3.7 \%$ respectively.

21 Among the other outcomes, physician global assessment and work were the most 22 frequent, reported in 14/27 (51.9\%) and 11/27 (40.7\%) registries respectively. Stiffness 23 was reported in 4/27 (14.8\%) whereas sleep, treatment burden and independence 24 were reported each in $1 / 27(3.7 \%)$ study. 


\subsection{Comparison of more recent versus less recent registries/cohorts}

2 Fifteen of the 27 PsA registries and cohorts were initiated after 2007. No significant difference was seen in the frequency of reporting of domains in registries/cohorts which were started before or after 2007 (Table 2, statistical comparisons not shown).

\section{DISCUSSION}

This systematic review puts to light an important heterogeneity in the assessment of disease activity in PsA. In 27 recently published registries/cohorts, 58 different clinical outcome measures were used. Disease activity composite scores were reported in 20 of 27 (74\%) PsA registries: most frequently through MDA (41\%), DAS28 (33\%), and/or DAPSA (30\%). Almost all registries reported joint involvement and skin psoriasis, using variable joint counts, most frequently the $66 / 68$ joint count, whereas enthesitis (77\%), dactylitis (74\%), and axial involvement (52\%) were less frequently reported. The OMERACT/GRAPPA 2016 inner core set domains (11) were assessed with a varying frequency, from $96.3 \%$ for joint counts to $33.3 \%$ for fatigue.

This study has strengths and weaknesses. The literature search only screened papers referenced in PubMed-Medline and used simple key words; however, given the descriptive nature of this overview of outcome measures in PsA registries/cohorts, the 673 articles screened were sufficient to provide an informative snapshot of everyday 22 clinical practice in PsA; and the added value of other databases is under discussion.(22) The search was limited to articles published in the last 10 years, which may have missed some older publications. However, we wished to analyze current 
1 practices and thus to concentrate on recent or ongoing PsA registries/cohorts and to

2 reflect outcome measures in the era after the publication of the OMERACT/GRAPPA

3 PsA core set of domains in 2006. $(10,11)$ Only PsA-specific registries and cohorts were

4 selected; other registries including PsA patients along with other rheumatic diseases

5 were excluded to reflect data collection tailored for PsA. The selection of papers and

6 data collection were done separately by three authors. However, we often encountered

7 issues to identify and differentiate cohort studies from retrospective studies when

8 relying only on the methodology part. Therefore, besides collective agreement and

9 discussion between authors, study websites were consulted and key authors were contacted when needed. Due to great heterogeneity in the outcomes used, classifying

11 the outcome measures was not always intuitive; e.g., BASDAl can be considered as a

12 PRO but also reflects axial involvement.(26) Only published outcome measures were analyzed which can differ from the data collected in the registry/cohort. However, we extracted data on outcome measures from all the papers available reporting on the same registry/cohort. Finally, a meta-analysis was not performed, and risk of bias was not assessed, due to the descriptive aim of this research and the heterogeneity of the 17 studies.

In the last decade, an increasing number of PsA-specific registries/cohorts have emerged, with 15 of the 27 PsA registries and cohorts initiated after 2007. Interest has

21 grown among researchers regarding outcome measures in PsA, with the first PsA 22 GRAPPA-OMERACT core-set.(10) In parallel, registries and cohorts may be seen as a source to understand the disease course and possibly reflect current practices better than clinical trials.(19) 
1 In the recent registries and cohorts reviewed here, peripheral joint counts and skin

2 involvement were the only domains which were almost systematically assessed. This

3 may reflect a consensus on the importance of these 2 key aspects of PsA, and/or

4 agreement on the scores to use. The $66 / 68$ joint count was recently fully endorsed by

5 OMERACT in 2018 as the optimal instrument to measure peripheral arthritis, which is

6 a component of musculoskeletal disease activity in PsA.(27) The frequent use of the

7 66/68 joint count in our study indicates the agreement between practice and 8 recommendations.

Enthesitis and dactylitis were less often reported. The evaluation of enthesitis and

11 dactylitis in PsA is still unclear, as reflected by heterogeneity in clinical trials. $(9,28)$

12 Dactylitis is recognized as a poor prognostic factor in the EULAR recommendations.(29) Data from the Corrona registry have shown that patients with enthesitis and/or dactylitis had greater disease activity and were less likely to achieve MDA.(30) Also, patients with enthesitis had a higher functional impairment, more pain, and fatigue.(30) This underscores the need to better identify and assess these manifestations in PsA.

Axial involvement was reported in PsA (55.6\%). Overall, $15 \%$ of patients with PsA in the Toronto cohort developed axial PsA over 10 years of follow-up.(31) Although a

21 clear distinction is not always possible in daily practice, a recent study has shown that 22 ankylosing spondylitis (AS) with psoriasis seems to be a separate disease from axial 23 PsA due to differences in the demographics, genetics, disease activity and disease progression. $(32,33)$ Although axial PsA had worse peripheral arthritis compared to AS, AS patients had an earlier onset of their disease, a higher male predominance, were 
1 more likely to be HLAB27 positive, to present with a more severe axial disease and

2 were more likely to be treated with biologics.(32) Therefore, for a better understanding

3 of this emerging entity, spinal involvement is an important aspect to measure in

4 patients with PsA. Our study has shown that spinal assessment was mostly done by

5 clinical evaluation of the physician in the majority of the registries/cohorts (90\%), and/or

6 through the BASDAI questionnaire (60\%), and never with MRI (0\%). The assessment

7 of axial SpA should be further defined.(32)

In the present study, disease activity composite scores were reported in $74 \%$ of the registries, mostly through MDA, DAS28 and DAPSA. DAS28 is adapted from RA and

11 is not recommended to evaluate disease activity in PsA.(34) A 2017 international task-

12 force on treat-to-target management recommended two PsA-specific instruments to define the treatment target: MDA or DAPSA.(8) DAPSA is a unidimensional composite outcome centered only on joint activity, whereas MDA is a binary measure of disease state including skin, entheses and joints.(8) In the last GRAPPA meeting held in 2021 ASDAS was proposed as the composite score to use in clinical trials and MDA as the treatment target.(35) Although not frequently collected in registries and cohorts, PASDAS captures many aspects of PsA including joint counts, dactylitis, enthesitis, systemic inflammation, SF-36 items for quality of life as well as the patient's and physician's global assessment (36).

21 On the other hand, GRAPPA agreed that composite scores of disease activity such 22 as PASDAS or CPDAI should be modified to be feasible in routine clinical practice(37). 23 Therefore, shortened versions of these composite scores are being tested for use in 24 clinical practice and need further validation.(38) 
1 Concerning PROs, more than $3 / 4$ of the registries reported $\mathrm{HAQ}$ and the other frequently

2 collected PROs were pain and patient global assessment which are all part of

3 MDA.(39) Fatigue was recently considered as an important topic mainly because of its

4 impact on quality of life.(40) It is also part of the main inner core-set; however, in our

5 study, fatigue was reported in only $1 / 3$ of the PsA registries or cohorts. In Palominos'

6 systematic review on PsA RCTs, fatigue was described in only $15.5 \%$ of articles.(9)

7 Thus, it seems that fatigue is being increasingly collected. Fatigue has been studied

8 mainly in RA(41-43) and more comprehensive data is awaited in PsA.(44) The PsA

9 Impact of Disease score (PsAID) was not reported in the registries, probably because

10 the vast majority of the registries started before 2014, when the PSAID was first

11 developed.(45)

12

13 The present study highlights great heterogeneity in outcome measures in PsA. Similar

14 work on RCTs also evidenced heterogeneity in the evaluation of disease activity in

15 PsA. $(9,28)$ However, registries and longitudinal cohorts may reflect more closely real-

16 world data than trials. In this regard, Radner et al observed heterogeneity in disease

17 activity outcomes in RA registries/cohorts. Such heterogeneity leads to difficulties in

comparing outcomes and studies.(19) Therefore, there is a need to obtain a consensus

on instruments to assess each domain and on outcome measures to be reported

homogeneously in studies and registries. This will enable a better evaluation and

21 comparability of the effectiveness of interventions, as well as improving the quality of

22 observational research. Only 11 registries/cohorts collected all of the 2006 core set

23 domains and only 2 registries/cohorts reported all of the 2016 updated 8 core set

24 domains. This finding shows a lack of implementation of the GRAPPA/OMERACT

25 consensus on important domains to assess in PsA.(11) 


\section{CONCLUSIONS}

3

4 Overall, although there is an increasing number of PsA-specific registries and cohorts,

5 data collection is still very heterogeneous, reflecting the need for international

6 consensus on outcome measures. Consensus initiatives are ongoing and may allow

7 better standardisation in the future.(46)

8

9 
1 ACKNOWLEDGMENTS AND AFFILIATIONS: none.

2 COMPETING INTERESTS: The authors have no relevant disclosures.

3 FUNDING, GRANT/AWARD INFO: none.

4 ETHICAL APPROVAL INFORMATION: not applicable.

5 DATA SHARING STATEMENT: All data relevant to the study are included in the

6 article or uploaded as supplementary information.

7 The protocol was registered on PROSPERO (CRD42020175745).

8 AUTHOR CONTRIBUTIONS:

9 K. Aouad contributed to: conceptualization, Methodology, Investigation, Formal 10 analysis and interpretation, Data curation, Writing- Original draft \& Editing, 11 visualization, Project administration, Final approval of the version to be published.

12 G. Moysidou, A. Rakotozafiarison contributed to: Methodology, Investigation, Project 13 administration, visualization, Writing- Review \& Editing, Final approval of the version 14 to be published.

15 B. Fautrel contributed to: Supervision, Validation, Writing- Review \& Editing, Final 16 approval of the version to be published

17 L. Gossec contributed to: Conceptualization, Methodology, Validation, investigation, 18 Formal analysis and interpretation, Writing- Review \& Editing, Supervision, Final 19 approval of the version to be published. 


\section{REFERENCES}

1. Gladman DD, Antoni C, Mease P, Clegg DO, Nash P. Psoriatic arthritis: epidemiology, clinical features, course, and outcome. Ann Rheum Dis. 2005 Mar;64 Suppl 2:ii14-17.

2. Ritchlin CT, Colbert RA, Gladman DD. Psoriatic Arthritis. N Engl J Med. 2017 09;376(10):957-70.

3. Ogdie A, Weiss P. The Epidemiology of Psoriatic Arthritis. Rheum Dis Clin North Am. 2015 Nov;41(4):545-68.

4. Gladman DD, Inman RD, Cook RJ, Maksymowych WP, Braun J, Davis JC, et al. International spondyloarthritis interobserver reliability exercise--the INSPIRE study: II. Assessment of peripheral joints, enthesitis, and dactylitis. J Rheumatol. 2007 Aug;34(8):1740-5.

5. Coates L. Outcome Measures in Psoriatic Arthritis. Rheum Dis Clin North Am. 2015 Nov;41(4):699-710.

6. Leung YY, Ogdie A, Orbai A-M, Tillett W, Coates LC, Strand V, et al. Classification and Outcome Measures for Psoriatic Arthritis. Front Med [Internet]. 2018 Sep 6 [cited 2020 Nov 9];5. Available from: https://www.ncbi.nIm.nih.gov/pmc/articles/PMC6135872/

7. Coates LC, Gossec L, Ramiro S, Mease P, van der Heijde D, Smolen JS, et al. New GRAPPA and EULAR recommendations for the management of psoriatic arthritis. Rheumatol Oxf Engl. 2017 01;56(8):1251-3.

8. Smolen JS, Schöls M, Braun J, Dougados M, FitzGerald O, Gladman DD, et al. Treating axial spondyloarthritis and peripheral spondyloarthritis, especially psoriatic arthritis, to target: 2017 update of recommendations by an international task force. Ann Rheum Dis. 2018;77(1):3-17.

9. Palominos PE, Gaujoux-Viala C, Fautrel B, Dougados M, Gossec L. Clinical outcomes in psoriatic arthritis: A systematic literature review. Arthritis Care Res. 2012 Mar;64(3):397-406.

10. Gladman DD, Mease PJ, Strand V, Healy P, Helliwell PS, Fitzgerald O, et al. Consensus on a core set of domains for psoriatic arthritis. J Rheumatol. 2007 May;34(5):1167-70.

11. Orbai A-M, de Wit M, Mease $P$, Shea JA, Gossec L, Leung YY, et al. International patient and physician consensus on a psoriatic arthritis core outcome set for clinical trials. Ann Rheum Dis. 2017;76(4):673-80.

12. Leung YY, Orbai A-M, Ogdie A, Coates LC, de Wit M, Callis Duffin $K$, et al. The GRAPPA-OMERACT Psoriatic Arthritis Working Group at the 2018 Annual Meeting: Report and Plan for Completing the Core Outcome Measurement Set. J Rheumatol Suppl. 2019 Jun;95:33-7.

13. Mease PJ. Measures of psoriatic arthritis: Tender and Swollen Joint Assessment, Psoriasis Area and Severity Index (PASI), Nail Psoriasis Severity Index (NAPSI), Modified Nail Psoriasis Severity Index (mNAPSI), Mander/Newcastle Enthesitis Index (MEI), Leeds Enthesitis Index (LEI), Spondyloarthritis Research Consortium of Canada (SPARCC), Maastricht Ankylosing Spondylitis Enthesis Score (MASES), Leeds Dactylitis Index (LDI), Patient Global for Psoriatic Arthritis, Dermatology Life Quality Index (DLQI), Psoriatic Arthritis Quality of Life (PsAQOL), Functional Assessment of Chronic Illness Therapy-Fatigue (FACIT-F), Psoriatic Arthritis Response Criteria (PsARC), Psoriatic Arthritis Joint Activity Index (PsAJAI), Disease Activity in Psoriatic Arthritis (DAPSA), and Composite Psoriatic Disease Activity Index (CPDAI). Arthritis Care Res. 2011 Nov;63 Suppl 11:S64-85. 
14. Hagège B, Tan E, Gayraud M, Fautrel B, Gossec L, Mitrovic S. Remission and low disease activity in psoriatic arthritis publications: a systematic literature review with meta-analysis. Rheumatol Oxf Engl. 2020 Mar 2;

15. van Mens LJ, van de Sande MGH, van Kuijk AWR, Baeten D, Coates LC. Ideal target for psoriatic arthritis? Comparison of remission and low disease activity states in a real-life cohort. Ann Rheum Dis. 2018;77(2):251-7.

16. Coates LC, Fransen J, Helliwell PS. Defining minimal disease activity in psoriatic arthritis: a proposed objective target for treatment. Ann Rheum Dis. 2010 Jan;69(1):48-53.

17. Gossec L, McGonagle D, Korotaeva T, Lubrano E, de Miguel E, Østergaard M, et al. Minimal Disease Activity as a Treatment Target in Psoriatic Arthritis: A Review of the Literature. J Rheumatol. 2018;45(1):6-13.

18. Gliklich RE, Dreyer NA, Leavy MB. Patient Registries [Internet]. Registries for Evaluating Patient Outcomes: A User's Guide [Internet]. 3rd edition. Agency for Healthcare Research and Quality (US); 2014 [cited 2020 Mar 25]. Available from: https://www.ncbi.nlm.nih.gov/books/NBK208643/

19. Radner H, Dixon W, Hyrich K, Askling J. Consistency and Utility of Data Items Across European Rheumatoid Arthritis Clinical Cohorts and Registers. Arthritis Care Res. 2015 Sep;67(9):121929.

20. Higgins J, Green S. Cochrane handbook for systematic reviews of interventions version 5.1.0 2011]. London: The Cochrane Collaboration. [Internet]. 2011. Available from: http://www.cochrane-handbook.org.

21. Outcomes used to collect disease activity in psoriatic arthritis registries: a systematic literature review. [Internet]. [cited 2020 Jun 13]. Available from:

https://www.crd.york.ac.uk/prospero/display_record.php?ID=CRD42020175745

22. Frandsen TF, Eriksen MB, Hammer DMG, Christensen JB, Wallin JA. Using Embase as a supplement to PubMed in Cochrane reviews differed across fields. J Clin Epidemiol. 2021 Jan 8;133:24-31.

23. Gladman DD, Landewé R, McHugh NJ, Fitzgerald $O$, Thaci $D$, Coates $L$, et al. Composite measures in psoriatic arthritis: GRAPPA 2008. J Rheumatol. 2010 Feb;37(2):453-61.

24. Ogdie A, Coates LC, Mease P. Measuring Outcomes in Psoriatic Arthritis. Arthritis Care Res. 2020;72 Suppl 10:82-109.

25. Taylor W, Gladman D, Helliwell P, Marchesoni A, Mease P, Mielants H, et al. Classification criteria for psoriatic arthritis: development of new criteria from a large international study. Arthritis Rheum. 2006 Aug;54(8):2665-73.

26. Fernández-Sueiro JL, Willisch A, Pértega-Díaz S, Tasende JAP, Fernández-López JC, Villar NO, et al. Validity of the bath ankylosing spondylitis disease activity index for the evaluation of disease activity in axial psoriatic arthritis. Arthritis Care Res. 2010 Jan 15;62(1):78-85.

27. Duarte-García A, Leung YY, Coates LC, Beaton D, Christensen R, Craig ET, et al. Endorsement of the 66/68 Joint Count for the Measurement of Musculoskeletal Disease Activity: OMERACT 2018 Psoriatic Arthritis Workshop Report. J Rheumatol. 2019 Aug;46(8):996-1005. 
28. Ramiro S, Smolen JS, Landewé R, Heijde D van der, Gossec L. How are enthesitis, dactylitis and nail involvement measured and reported in recent clinical trials of psoriatic arthritis? A systematic literature review. Ann Rheum Dis. 2018;77(5):782-3.

29. Gossec L, Baraliakos X, Kerschbaumer A, de Wit M, Mclnnes I, Dougados M, et al. EULAR recommendations for the management of psoriatic arthritis with pharmacological therapies: 2019 update. Ann Rheum Dis. 2020 Jun;79(6):700-12.

30. Mease PJ, Karki C, Palmer JB, Etzel CJ, Kavanaugh A, Ritchlin CT, et al. Clinical Characteristics, Disease Activity, and Patient-Reported Outcomes in Psoriatic Arthritis Patients With Dactylitis or Enthesitis: Results From the Corrona Psoriatic Arthritis/Spondyloarthritis Registry. Arthritis Care Res. 2017 Nov;69(11):1692-9.

31. Chandran V, Tolusso DC, Cook RJ, Gladman DD. Risk factors for axial inflammatory arthritis in patients with psoriatic arthritis. J Rheumatol. 2010 Apr;37(4):809-15.

32. Feld J, Ye JY, Chandran V, Inman RD, Haroon N, Cook R, et al. Is axial psoriatic arthritis distinct from ankylosing spondylitis with and without concomitant psoriasis? Rheumatol Oxf Engl. 2020 Jun 1;59(6):1340-6.

33. Feld J, Chandran V, Gladman DD. What Is Axial Psoriatic Arthritis? J Rheumatol. 2018 Dec;45(12):1611-3.

34. Wervers K, Luime JJ, Tchetverikov I, Gerards AH, Kok MR, Appels CWY, et al. Comparison of disease activity measures in early psoriatic arthritis in usual care. Rheumatol Oxf Engl. 2019 Dec;58(12):2251-9.

35. Tillett W, FitzGerald O, Coates LC, Packham J, Jadon DR, Massarotti M, et al. Composite Measures for Clinical Trials in Psoriatic Arthritis: Testing Pain and Fatigue Modifications in a UK Multicenter Study. J Rheumatol. 2021 Mar 1; jrheum.201674. doi: 10.3899/jrheum.201674.

36. Helliwell PS, FitzGerald O, Fransen J, Gladman DD, Kreuger GG, Callis-Duffin K, et al. The development of candidate composite disease activity and responder indices for psoriatic arthritis (GRACE project). Ann Rheum Dis. 2013 Jun;72(6):986-91.

37. Tillett $W$, McHugh N, Orbai A-M, Ogdie A, Leung YY, Coates LC, et al. Outcomes of the 2019 GRAPPA Workshop on Continuous Composite Indices for the Assessment of Psoriatic Arthritis and Membership-recommended Next Steps. J Rheumatol Suppl. 2020 Jun;96:11-8.

38. Tillett W, FitzGerald O, Coates LC, Packham J, Jadon DR, Massarotti M, et al. Composite Measures for Routine Clinical Practice in Psoriatic Arthritis: Testing of Shortened Versions in a UK Multicenter Study. J Rheumatol. 2021 Mar 1; jrheum.201675. doi: 10.3899/jrheum.201675

39. Coates LC, Strand V, Wilson H, Revicki D, Stolshek B, Samad A, et al. Measurement properties of the minimal disease activity criteria for psoriatic arthritis. RMD Open. 2019;5(2):e001002.

40. Gudu T, Gossec L. Quality of life in psoriatic arthritis. Expert Rev Clin Immunol. 2018 May;14(5):405-17.

41. Holdren M, Schieir O, Bartlett SJ, Bessette L, Boire G, Hazlewood G, et al. Improvements in Fatigue Lag Behind Disease Remission in Early Rheumatoid Arthritis: Results from the Canadian Early Arthritis Cohort. Arthritis Rheumatol Hoboken NJ. 2020 Aug 27; 
42. Hewlett S, Chalder T, Choy E, Cramp F, Davis B, Dures E, et al. Fatigue in rheumatoid arthritis: time for a conceptual model. Rheumatol Oxf Engl. 2011 Jun;50(6):1004-6.

43. Choy EH, Dures E. Fatigue in rheumatoid arthritis. Rheumatol Oxf Engl. 2019 01;58(Suppl 5):v1-2.

44. Palominos PE, Coates L, Kohem CL, Orbai A-M, Smolen J, de Wit M, et al. Determinants of sleep impairment in psoriatic arthritis: An observational study with 396 patients from 14 countries. Joint Bone Spine. 2020 Oct;87(5):449-54.

45. Gossec L, de Wit M, Kiltz U, Braun J, Kalyoncu U, Scrivo R, et al. A patient-derived and patientreported outcome measure for assessing psoriatic arthritis: elaboration and preliminary validation of the Psoriatic Arthritis Impact of Disease (PSAID) questionnaire, a 13-country EULAR initiative. Ann Rheum Dis. 2014 Jun;73(6):1012-9.

46. Leung YY, Tillett W, Orbai A-M, Ogdie A, Eder L, Coates LC, et al. The GRAPPA-OMERACT Working Group: 4 Prioritized Domains for Completing the Core Outcome Measurement Set for Psoriatic Arthritis 2019 Updates. J Rheumatol Suppl. 2020 Jun;96:46-9. 
3 Figure 1. Flow Diagram of PsA registries and cohorts published between 2010 4 and March 2020.

Articles identified through MEDLINE

$$
(n=673)
$$

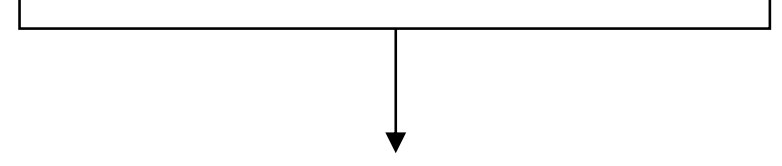

Articles screened

$(n=673)$

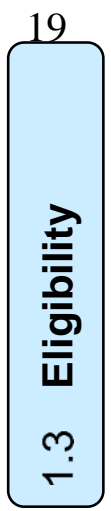

\begin{tabular}{|l}
26 \\
웡 \\
$\frac{2}{2}$ \\
드 \\
ㅁ. \\
\hline
\end{tabular}

Articles analysed $(n=73)$ reporting on 27 registries or cohorts
Publication excluded on the basis of titles and abstracts $(n=$ 445)

1- Not a registry or longitudinal cohort $(n=173)$

2- Not a registry centered on PsA $(n=116)$

3- Not PsA patients $(n=107)$

4- No clinical outcomes $(n=1)$

5- $\quad$ N patients $<50(n=7)$

6- Not adult $(n=8)$

7- Not english $(n=33)$

Articles excluded on the basis of full-text $(n=155)$

1- Not a registry or longitudinal cohort $(n=97)$

2- Not a registry centered on PsA $(n=29)$

3- Not PsA patients $(n=3)$

4- No clinical outcomes $(n=18)$

5- N patients $<50 \quad(n=3)$

6- Not English $(n=4)$

7- No access to full-text $(n=1)$ 
1 Figure 2. Frequency of reporting of different composite scores and outcome 2 measures in 27 PsA registries/cohorts

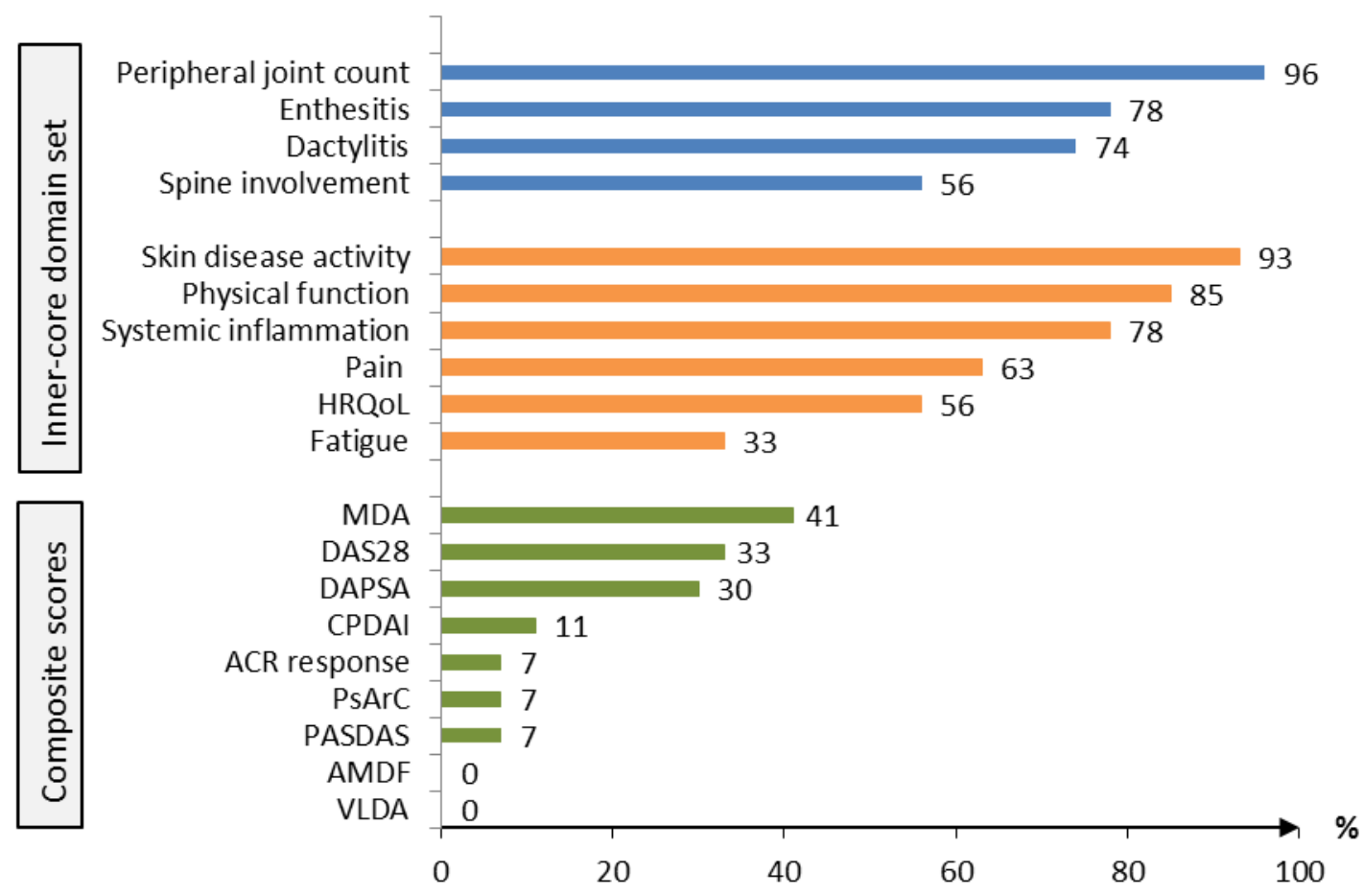

4 The bars represent the percentage of the 27 PsA registries/cohorts. The blue bars 5 represent the musculoskeletal disease activity, the orange bars represent the other 6 domains of the inner-core set, and the green bars represent the composite disease 7 activity scores.

9 ACR response: American College of Rheumatology response; AMDF: Arithmetic Mean of the 10 Desirability Function; CPDAl: Composite Psoriatic Disease Activity Index; DAS28: Disease Activity 11 Score 28; DAPSA: Disease Activity in PSoriatic Arthritis; HRQoL: Health-Related Quality of Life; 12 PASDAS: Psoriatic Arthritis Disease Activity Score; PsArC: Psoriatic Arthritis Response Criteria; MDA:

13 Minimal Disease Activity; VLDA: Very Low Disease Activity. 
1 Table 1. Summary description of 27 PsA registries/cohorts

2

\begin{tabular}{|l|l|}
\hline & $\begin{array}{l}\text { Total N =16,183 patients } \\
(\mathrm{n}=27 \text { registries })\end{array}$ \\
\hline Age of patients, weighted mean, years (SD) & $49.7(9.3)$ \\
\hline Diagnosis based on CASPAR, N (\%) & $21(77.8)$ \\
\hline Gender, female, N (\%) & $7959(49.2)$ \\
\hline Disease duration, weighted mean, years (SD) & $6.8(0.2)$ \\
\hline Study involving a single center, N (\%) & $12(44.4)$ \\
\hline Number of patients per study, mean (SD) & $599(578)$ \\
\hline Inception cohorts for early disease (S3years), N (\%) & $4 / 26(15.4)$ \\
\hline
\end{tabular}

3 CASPAR: Classification Criteria for Psoriatic Arthritis (25). 
Table 2. Frequency of reporting of inner core set domains and outcome measures in 73 publications pertaining to 27 PsA cohorts/registries

\begin{tabular}{|c|c|c|c|c|c|}
\hline PsA domains & $\begin{array}{l}\text { Studies reporting } \\
\text { the domain, } n \text { ( } \% \\
\text { of } 27 \text { registries) }\end{array}$ & $\begin{array}{l}\text { Cohort/registry } \\
\text { starting before } \\
2007, \mathrm{n} \text { (\% of } 12 \\
\text { registries) }\end{array}$ & 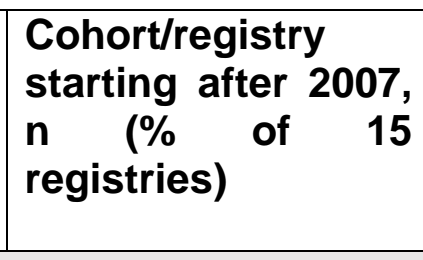 & $\begin{array}{l}\text { Main outcome } \\
\text { measures used to } \\
\text { assess each domain }\end{array}$ & $\begin{array}{l}\text { Studies reporting } \\
\text { the outcome } \\
\text { measure, } \mathrm{n} \% \text { of } \\
\text { registries reporting } \\
\text { the domains) }\end{array}$ \\
\hline \multicolumn{6}{|c|}{ Inner core set domains } \\
\hline $\begin{array}{l}\text { Peripheral joint } \\
\text { count }^{1}\end{array}$ & $26(96.3)$ & 11 (91.6) & $15(100.0)$ & \begin{tabular}{|l|} 
Tender joint count 68 \\
Swollen joint count 66 \\
Damaged joint count
\end{tabular} & $\begin{array}{l}14(53.8) \\
14(53.8) \\
7(26.9)\end{array}$ \\
\hline Enthesitis $^{2}$ & $21(77.7)$ & $9(75.0)$ & $12(80.0)$ & $\begin{array}{l}\text { Leeds enthesitis index } \\
\text { MASES }\end{array}$ & $\begin{array}{l}7(33.3) \\
5(23.8) \\
\end{array}$ \\
\hline Dactylitis $^{3}$ & $20(74.1)$ & $9(75.0)$ & $11(73.3)$ & $\begin{array}{l}\text { Number of digits } \\
\text { Leeds Dactylitis Index }\end{array}$ & $\begin{array}{l}11(55.0) \\
1(5.0)\end{array}$ \\
\hline $\begin{array}{l}\text { Spine } \\
\text { involvement }\end{array}$ & $15(55.6)$ & $6(50.0)$ & $9(60.0)$ & $\begin{array}{l}\text { Physician } \\
\text { assessment } \\
\text { BASDAl } \\
\end{array}$ & $\begin{array}{l}14(93.3) \\
9(60.0) \\
\end{array}$ \\
\hline $\begin{array}{l}\text { Skin disease } \\
\text { activity }^{4}\end{array}$ & $25(92.6)$ & $11(91.6)$ & $14(93.3)$ & $\begin{array}{l}\text { PASI } \\
\text { Body surface area }\end{array}$ & \begin{tabular}{|l}
$18(95.7)$ \\
$12(48.0)$
\end{tabular} \\
\hline $\begin{array}{l}\text { Physical } \\
\text { function }^{5}\end{array}$ & $23(85.2)$ & $9(75.0)$ & 14 (93.3) & $\mathrm{HAQ}$ & $22(95.7)$ \\
\hline HRQoL 6 & $15(55.5)$ & $7(58.3)$ & $8(53.3)$ & $\begin{array}{l}\text { SF36 } \\
\text { DLQI } \\
\text { EuroQol-5 Domain }\end{array}$ & $\begin{array}{l}7(46.7) \\
7(46.7) \\
7(46.7)\end{array}$ \\
\hline Fatigue & $9(33.3)$ & $2(16.6)$ & $7(46.6)$ & Fatigue analog scale & $5(55.6)$ \\
\hline $\begin{array}{l}\text { Systemic } \\
\text { inflammation }\end{array}$ & $21(77.7)$ & $10(83.3)$ & $11(73.3)$ & \begin{tabular}{|l} 
CRP \\
Erythrocyte \\
sedimentation rate
\end{tabular} & $\begin{array}{l}19(90.5) \\
17(81.0) \\
\end{array}$ \\
\hline
\end{tabular}




\begin{tabular}{|l|l|l|l|l|l|}
\hline Pain & $17(62.9)$ & $7(58.3)$ & $10(66.6)$ & Pain analog scale & $17(100.0)$ \\
\hline $\begin{array}{l}\text { Patient global } \\
\text { assessment }\end{array}$ & $19(70.3)$ & $7(58.3)$ & $12(75.0)$ & PGA analog scale & $19(100.0)$ \\
\hline $\begin{array}{l}\text { Composite } \\
\text { scores }\end{array}$ & $17(63.0)$ & $7(58.3)$ & $10(66.7)$ & & \\
\hline \multicolumn{1}{|c|}{ MDA } & $11(40.7)$ & $6(50.0)$ & $5(33.3)$ & & \\
\hline $\begin{array}{l}\text { DAS28 or } \\
\text { rULAR } \\
\text { response }\end{array}$ & $9(33.3)$ & $4(33.3)$ & $5(33.3)$ & & \\
\hline DAPSA & $8(29.6)$ & $4(33.3)$ & $4(26.6)$ & & \\
\hline
\end{tabular}

${ }^{1}$ binary assessment of joint count 4/27 (14.8\%), tender and swollen joint count (28 and 44): $0 \%$ not reported

2 Spondyloarthritis Research Consortium of Canada Enthesitis Index: $3 / 27$ (11.1\%)

${ }^{3}$ Leeds dactylitis Index: $1 / 27$ (3.7\%)

${ }^{4}$ Physician global assessment of psoriasis 4/27 (14.8\%)

5 Bath Ankylosing Spondylitis Functional Index (BASFI): 4/27(14.8\%), Modified HAQ: $1 / 27$ (3.7\%). Revised Leeds Disability Questionnaire, Advanced Activities of Daily Living Scale, Psoriasis Disability index (0\%) were not reported.

6 Psoriatic Arthritis Quality of Life (PsAQoL): 4/27 (14.8\%), Short Form 12 Health Survey: 1/27(3.7\%), Ankylosing Spondylitis quality of life score: $1 / 27(3.7 \%)$, Comprehensive Assessment of the Psoriasis Patient $(C A P P): 1 / 27(3.7 \%)$, Psoriatic Arthritis Impact of Disease (PsAID, 0\%).

7 Other composite scores were: CPDAI: 3/27(11.1\%), PASDAS: 2/27 (7.4\%), American College of Rheumatology (ACR) response: 2/27 (7.4\%), Psoriatic Arthritis Response Criteria (PsARC): 2/27(7.4\%), other scores (VLDA, AMDF, 0\%) were not reported. 
AMDF: Arithmetic Mean of the Desirability Function; BASDAl: Bath Ankylosing Spondylitis Disease Activity Index; CPDAl: Composite Psoriatic Disease Activity Index; DAPSA: Disease Activity in PSoriatic Arthritis; DLQI: Dermatology Life Quality Index; HAQ: Health assessment Questionnaire; HRQoL: Health Related Quality of Life; MASES: Maastricht Ankylosing Spondylitis Enthesitis Score; MDA: Minimal Disease Activity; PASDAS: Psoriatic Arthritis Disease Activity Score; PASI: Psoriasis Area Severity Index; PGA: Patient's global assessment; SF-36: 36-item short-form health survey; VAS: Visual Analogue Score; VLDA: Very Low Disease Activity. 
The 73 publications selected by the systematic literature review and reporting on 27 registries or longitudinal cohorts in psoriatic arthritis and published between 2010 and 2020.

\begin{tabular}{|c|c|c|}
\hline $\begin{array}{c}\text { Registry or Cohort } \\
\text { Name/Abbreviation/Origin }\end{array}$ & $\begin{array}{c}\text { Country from } \\
\text { which the data } \\
\text { originate }\end{array}$ & Reference \\
\hline Adelphi PsA & 18 countries & $\begin{array}{l}\text { Alten R, Conaghan PG, Strand V, Sullivan } \\
\text { E, Blackburn S, Tian H, et al. Unmet } \\
\text { needs in psoriatic arthritis patients } \\
\text { receiving immunomodulatory therapy: } \\
\text { results from a large multinational real- } \\
\text { world study. Clin Rheumatol. } 2019 \\
\text { Jun;38(6):1615-26 } \\
\text { Furst DE, Tran M, Sullivan E, Pike J, } \\
\text { Piercy J, Herrera V, et al. Misalignment } \\
\text { between physicians and patient } \\
\text { satisfaction with psoriatic arthritis disease } \\
\text { control. C Clin } 2017 ; 36(9): 2045-54 .\end{array}$ \\
\hline BATH UK cohort & UK & $\begin{array}{l}\text { Holland R, Tillett W, Korendowych E, } \\
\text { Cavill C, Waldron N, Brooke M, et al. } \\
\text { Validation of the Psoriatic Arthritis Impact } \\
\text { of Disease (PsAID) Questionnaire and its } \\
\text { potential as a single-item outcome } \\
\text { measure in clinical practice. Ann Rheum } \\
\text { Dis. 2018;77(3):343-7 }\end{array}$ \\
\hline BRAZIL PSA cohort & Brazil & $\begin{array}{l}\text { Ferreira, M.F., Kohem, C.L., Xavier, } \\
\text { R.M. et al. Treating psoriatic arthritis to } \\
\text { target: discordance between physicians } \\
\text { and patients assessment, non- } \\
\text { adherence, and restricted access to drugs } \\
\text { precluded therapy escalation in a real- } \\
\text { world cohort. Clin Rheumatol 2019; } \\
\text { 38, 961-968 }\end{array}$ \\
\hline \multirow[t]{2}{*}{ CAMPOBASSO } & \multirow[t]{2}{*}{ Italy } & $\begin{array}{l}\text { Lubrano E, Parsons WJ, Perrotta FM. } \\
\text { Assessment of Response to Treatment, } \\
\text { Remission, and Minimal Disease Activity } \\
\text { in Axial Psoriatic Arthritis Treated with } \\
\text { Tumor Necrosis Factor Inhibitors. J } \\
\text { Rheumatol. } 2016 \text { May;43(5):918-23 }\end{array}$ \\
\hline & & $\begin{array}{l}\text { Lubrano E, Perrotta FM, Parsons WJ, } \\
\text { Marchesoni A. Patient's Global } \\
\text { Assessment as an Outcome Measure for } \\
\text { Psoriatic Arthritis in Clinical Practice: A } \\
\text { Surrogate for Measuring Low Disease } \\
\text { Activity? J Rheumatol. } 2015 \\
\text { Dec;42(12):2332-8 }\end{array}$ \\
\hline CARMA & Spain & $\begin{array}{l}\text { García-Gómez C, Martín-Martínez MA, } \\
\text { Fernández-Carballido C, Castañeda S, } \\
\text { González-Juanatey C, Sanchez-Alonso F, } \\
\text { González-Fernández MJ, Sanmartí R, } \\
\text { García-Vadillo JA, Fernández-Gutiérrez } \\
\text { B, García-Arias M, Manero FJ, Senabre } \\
\text { JM, Rueda-Cid A, Ros-Expósito S, Pina- } \\
\text { Salvador JM, Erra-Durán A, Möller-Parera }\end{array}$ \\
\hline
\end{tabular}




\begin{tabular}{|c|c|c|}
\hline & & $\begin{array}{l}\text { I, Llorca J, González-Gay MA; CARMA } \\
\text { Project Collaborative Group. } \\
\text { Hyperlipoproteinaemia(a) in patients with } \\
\text { spondyloarthritis: results of the } \\
\text { Cardiovascular in Rheumatology } \\
\text { (CARMA) project. Clin Exp Rheumatol. } \\
\text { 2019 Sep-Oct:37(5):774-782 }\end{array}$ \\
\hline CARVALHO PsA cohort & Spain & $\begin{array}{l}\text { Carvalho PD, Savy F, Moragues C, } \\
\text { Juanola X, Rodriguez-Moreno J. Axial } \\
\text { involvement according to ASAS criteria in } \\
\text { an observational psoriatic arthritis cohort. } \\
\text { Acta Reumatol Port. } 2017 \text { Apr- } \\
\text { Jun;42(2):176-182 }\end{array}$ \\
\hline COMPASS & USA & $\begin{array}{l}\text { Dalal DS, Lin YC, Brennan DM, Borkar N, } \\
\text { Korman N, Husni ME. Quantifying harmful } \\
\text { effects of psoriatic diseases on quality of } \\
\text { life: Cardio-metabolic outcomes in } \\
\text { psoriatic arthritis study (COMPASS). } \\
\text { Semin Arthritis Rheum. } \\
\text { Jun;44(6):641-5 }\end{array}$ \\
\hline COPPAR & USA & $\begin{array}{l}\text { Schneeweiss M, Merola JF, Karlson EW, } \\
\text { Solomon DH. Rationale and Design of the } \\
\text { Brigham Cohort for psoriasis and psoriatic } \\
\text { arthritis registry (COPPAR). BMC } \\
\text { Dermatol. } 2017 \text { Aug 16;17(1):11. }\end{array}$ \\
\hline \multirow[t]{4}{*}{ CORRONA } & \multirow[t]{4}{*}{ USA } & $\begin{array}{l}\text { Mease PJ, Palmer JB, Hur P, Strober BE, } \\
\text { Lebwohl M, Karki C, Reed GW, Etzel CJ, } \\
\text { Greenberg JD, Helliwell PS. Utilization of } \\
\text { the validated Psoriasis Epidemiology } \\
\text { Screening Tool to identify signs and } \\
\text { symptoms of psoriatic arthritis among } \\
\text { those with psoriasis: a cross-sectional } \\
\text { analysis from the US-based Corrona } \\
\text { Psoriasis Registry. J Eur Acad Dermatol } \\
\text { Venereol. } 2019 \text { May;33(5):886-892 }\end{array}$ \\
\hline & & $\begin{array}{l}\text { Mease PJ, Palmer JB, Liu M, Kavanaugh } \\
\text { A, Pandurengan R, Ritchlin CT, Karki C, } \\
\text { Greenberg JD. Influence of Axial } \\
\text { Involvement on Clinical Characteristics of } \\
\text { Psoriatic Arthritis: Analysis from the } \\
\text { Corrona Psoriatic } \\
\text { Arthritis/Spondyloarthritis Registry. J } \\
\text { Rheumatol. } 2018 \text { Oct; } 45(10): 1389-1396 \\
\text { Kavanaugh A, Singh R, Karki C, Etzel CJ, } \\
\text { Kremer JM, Greenberg JD, Griffith J. } \\
\text { Disease activity and biologic use in } \\
\text { patients with psoriatic arthritis or } \\
\text { rheumatoid arthritis. Clin Rheumatol. } 2018 \\
\text { Aug;37(8):2275-2280 }\end{array}$ \\
\hline & & $\begin{array}{l}\text { Harrold LR, Stolshek BS, Rebello S, } \\
\text { Collier DH, Mutebi A, Wade SW, Malley } \\
\text { W, Greenberg JD, Etzel CJ. Rebound in } \\
\text { Measures of Disease Activity and } \\
\text { Symptoms in Corrona Registry Patients } \\
\text { with Psoriatic Arthritis Who Discontinue } \\
\text { Tumor Necrosis Factor Inhibitor Therapy } \\
\text { after Achieving Low Disease Activity. J } \\
\text { Rheumatol. } 2018 \text { Jan;45(1):78-82 }\end{array}$ \\
\hline & & $\begin{array}{l}\text { Mease PJ, Karki C, Palmer JB, Etzel CJ, } \\
\text { Kavanaugh A, Ritchlin CT, Malley W, }\end{array}$ \\
\hline
\end{tabular}




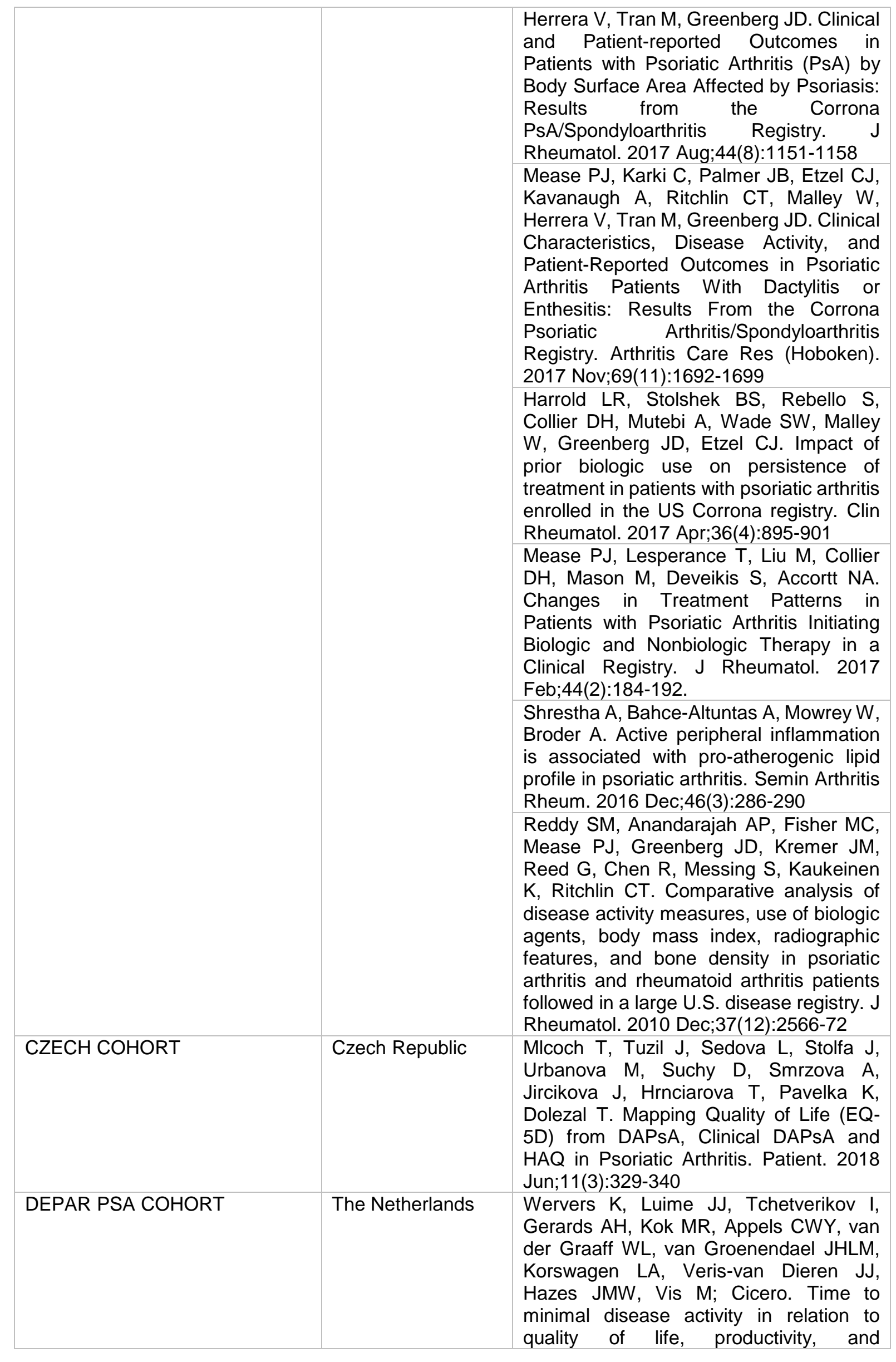




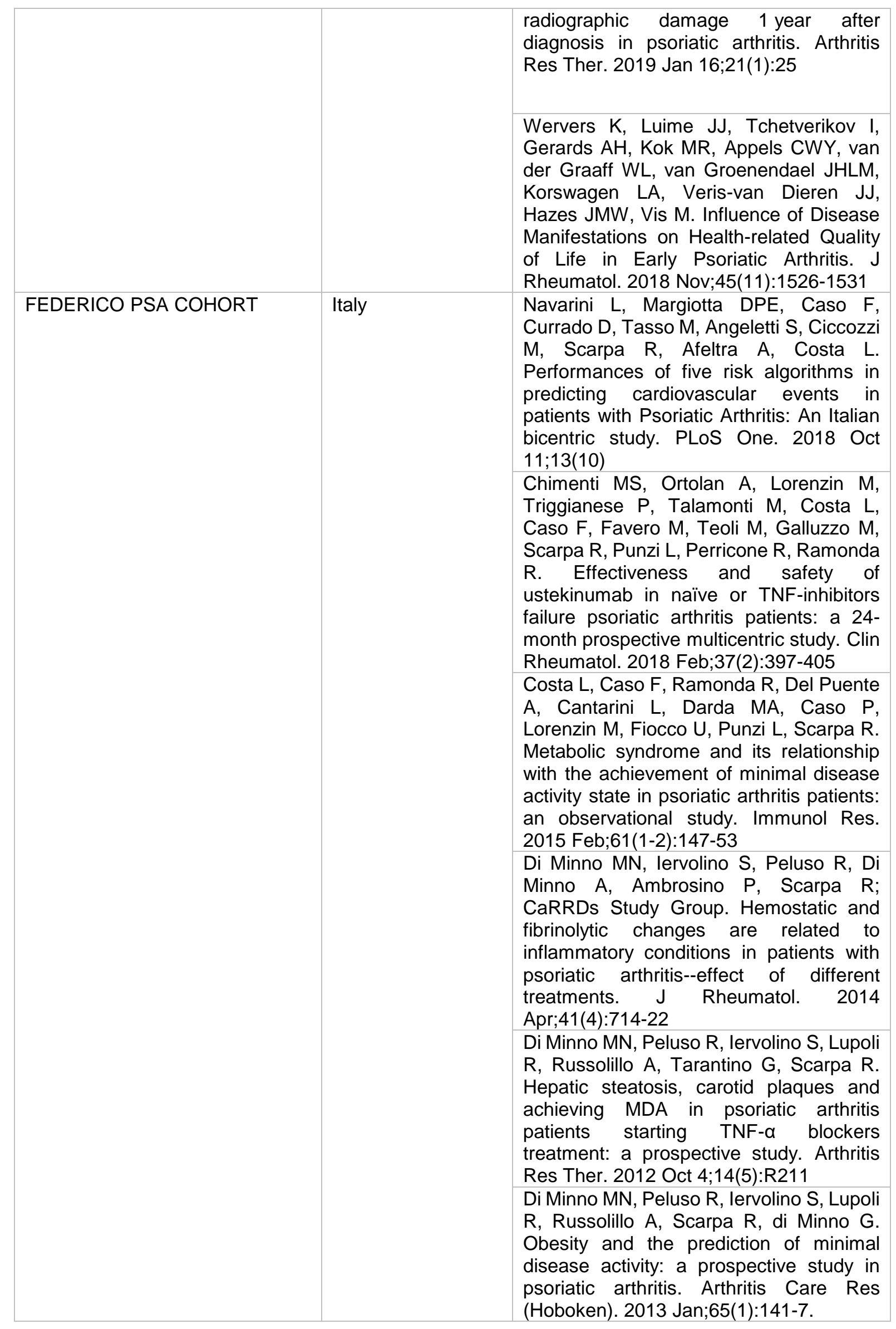




\begin{tabular}{|c|c|c|}
\hline & & $\begin{array}{l}\text { Atteno M, Peluso R, Costa L, Padula S, } \\
\text { lervolino S, Caso F, Sanduzzi A, Lubrano } \\
\text { E, Del Puente A, Scarpa R. Comparison } \\
\text { of effectiveness and safety of infliximab, } \\
\text { etanercept, and adalimumab in psoriatic } \\
\text { arthritis patients who experienced an } \\
\text { inadequate response to previous disease- } \\
\text { modifying antirheumatic drugs. Clin } \\
\text { Rheumatol. } 2010 \text { Apr;29(4):399-403 }\end{array}$ \\
\hline IPART & 3 countries & $\begin{array}{l}\text { Eder L, Harvey P, Chandran V, Rosen CF, } \\
\text { Dutz J, Elder JT, Rahman P, Ritchlin CT, } \\
\text { Rohekar S, Hayday R, Barac S, Feld J, } \\
\text { Zisman D, Gladman DD. Gaps in } \\
\text { Diagnosis and Treatment of } \\
\text { Cardiovascular Risk Factors in Patients } \\
\text { with Psoriatic Disease: An International } \\
\text { Multicenter Study. J Rheumatol. } 2018 \\
\text { Mar;45(3):378-384 }\end{array}$ \\
\hline LOPAS II & UK & $\begin{array}{l}\text { Tillett W, Shaddick G, Jobling A, Askari A, } \\
\text { Cooper A, Creamer P, Clunie G, Helliwell } \\
\text { PS, James J, Kay L, Korendowych E, } \\
\text { Lane S, Packham J, Shaban R, Thomas } \\
\text { ML, Williamson L, McHugh N. Effect of } \\
\text { anti-TNF and conventional synthetic } \\
\text { disease-modifying anti-rheumatic drug } \\
\text { treatment on work disability and clinical } \\
\text { outcome in a multicentre observational } \\
\text { cohort study of psoriatic arthritis. } \\
\text { Rheumatology (Oxford). } 2017 \text { Apr } \\
1 ; 56(4): 603-612 \\
\text { Tillett W, Shaddick G, Askari A, Cooper A, } \\
\text { Creamer P, Clunie G, Helliwell PS, Kay L, } \\
\text { Korendowych E, Lane S, Packham J, } \\
\text { Shaban R, Williamson L, McHugh N. } \\
\text { Factors influencing work disability in } \\
\text { psoriatic arthritis: first results from a large } \\
\text { UK multicentre study. Rheumatology } \\
\text { (Oxford). } 2015 \text { Jan;54(1):157-62 }\end{array}$ \\
\hline PRESPOND REGISTRY & China & $\begin{array}{l}\text { Wang CTM, Kwan YH, Fong W, Xiong SQ, } \\
\text { Leung YY. Factors associated with } \\
\text { patient-physician discordance in a } \\
\text { prospective cohort of patients with } \\
\text { psoriatic arthritis: An Asian perspective. } \\
\text { Int J Rheum Dis. } 2019 \text { Jul;22(7):1209- } \\
1215\end{array}$ \\
\hline PSART ID & 2 countries & $\begin{array}{l}\text { Bakirci S, Solmaz D, Al Osaimi N, Dalkilic } \\
\text { E, Can M, Erden A, Ozisler C, Cinar M, } \\
\text { Kilic L, Küçük A, Omma A, Yildiz F, Doğru } \\
\text { A, Tufan A, Esmen SE, Akar S, Kalyoncu } \\
\text { U, Aydin SZ; PsArt-ID (Psoriatic Arthritis- } \\
\text { International Database). What are the } \\
\text { main barriers to achieve minimal disease } \\
\text { activity in psoriatic arthritis in real life? Clin } \\
\text { Exp Rheumatol. } 2019 \text { Sep-Oct;37(5):808- } \\
812\end{array}$ \\
\hline & & $\begin{array}{l}\text { Aydin SZ, Kucuksahin O, Kilic L, Dogru A, } \\
\text { Bayindir O, Ozisler C, Omma A, Tarhan } \\
\text { EF, Erden A, Kimyon G, Can M, Dalkilic E, } \\
\text { Yavuz S, Ureyen SB, Gunal EK, Alhussain }\end{array}$ \\
\hline
\end{tabular}




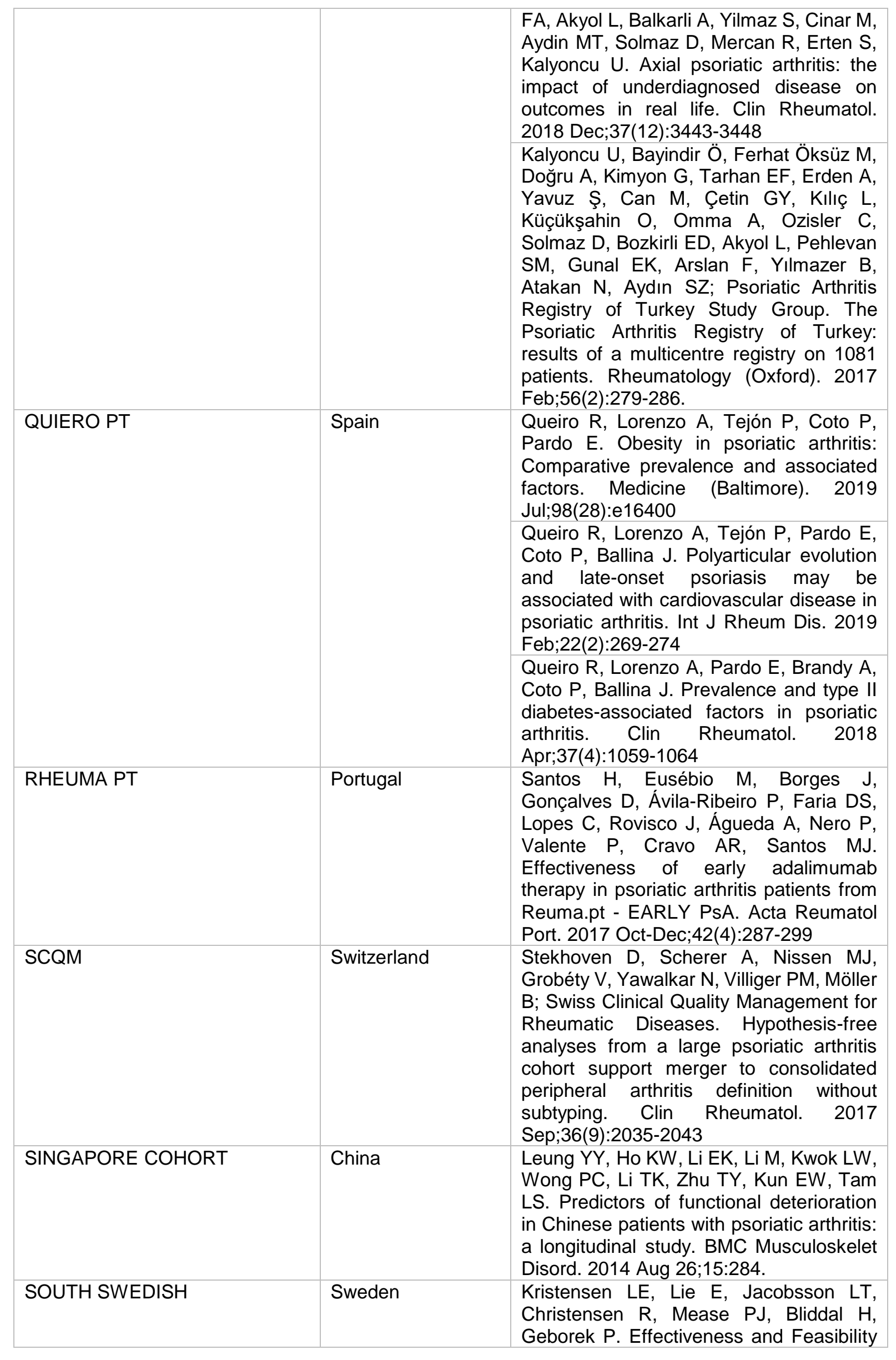




\begin{tabular}{|c|c|c|}
\hline & & $\begin{array}{l}\text { Associated with Switching to a Second or } \\
\text { Third TNF Inhibitor in Patients with } \\
\text { Psoriatic Arthritis: A Cohort Study from } \\
\text { Southern Sweden. J Rheumatol. } 2016 \\
\text { Jan; } 43(1): 81-7 \text {. } \\
\text { Kristensen LE, Englund M, Neovius M, } \\
\text { Askling J, Jacobsson LT, Petersson IF. } \\
\text { Long-term work disability in patients with } \\
\text { psoriatic arthritis treated with anti-tumour } \\
\text { necrosis factor: a population-based } \\
\text { regional Swedish cohort study. Ann } \\
\text { Rheum Dis. } 2013 \text { Oct; } 72(10): 1675-9 \text {. }\end{array}$ \\
\hline SWEPSA & Sweden & $\begin{array}{l}\text { Lindqvist U, Wernroth ML, Husmark T, } \\
\text { Larsson P, Geijer M, Teleman A, } \\
\text { Theander E, Alenius GM. DAPSA, DAS28 } \\
\text { and MDA predict long-term treatment } \\
\text { regime in psoriatic arthritis. The Swedish } \\
\text { Early Psoriatic Arthritis Cohort. Clin Exp } \\
\text { Rheumatol. 2017 Nov-Dec;35(6):936-942 } \\
\text { Geijer M, Lindqvist U, Husmark T, Alenius } \\
\text { GM, Larsson PT, Teleman A, Theander E. } \\
\text { The Swedish Early Psoriatic Arthritis } \\
\text { Registry 5-year Followup: Substantial } \\
\text { Radiographic Progression Mainly in Men } \\
\text { with High Disease Activity and } \\
\text { Development of Dactylitis. J Rheumatol. } \\
2015 \text { Nov; } 42(11): 2110-7 \\
\text { Theander E, Husmark T, Alenius GM, GM, } \\
\text { Larsson PT, Teleman A, Geijer M, } \\
\text { Lindqvist UR. Early psoriatic arthritis: } \\
\text { short symptom duration, male gender and } \\
\text { preserved physical functioning at at } \\
\text { presentation predict favourable outcome } \\
\text { at 5-year follow-up. Results from the } \\
\text { Swedish Early Psoriatic Arthritis Register } \\
\text { (SwePsA). Ann Rheum Dis. 2014 } \\
\text { Feb;73(2):407-13 }\end{array}$ \\
\hline SYNERGY & Italy & $\begin{array}{l}\text { Colombo D, Chimenti S, Grossi PA, } \\
\text { Marchesoni A, Foti R, Calzavara-Pinton P, } \\
\text { Zagni E, Ori A, Bellia G; SYNERGY Study } \\
\text { Group. Efficacy of cyclosporine A as } \\
\text { monotherapy in patients with psoriatic } \\
\text { arthritis: a subgroup analysis of the } \\
\text { SYNERGY Study. G Ital Dermatol } \\
\text { Venereol. } 2017 \text { Jun;152(3):297-301 } \\
\text { Colombo D, Chimenti S, Grossi P, } \\
\text { Marchesoni A, Di Nuzzo S, Griseta V, } \\
\text { Gargiulo A, Parodi A, Simoni L, Bellia G. } \\
\text { Prevalence of past and reactivated viral } \\
\text { infections and efficacy of cyclosporine A } \\
\text { as monotherapy or in combination in } \\
\text { patients with psoriatic arthritis--synergy } \\
\text { study: a longitudinal observational study. } \\
\text { Biomed Res Int. 2014;2014:941767 }\end{array}$ \\
\hline SZANTO & 6 countries & $\begin{array}{l}\text { Szántó S, Poór G, Opris D, laremenko O, } \\
\text { Procházková L, Kuuse R, Nagy O, } \\
\text { Chernyshov V, Géher P. Improved } \\
\text { clinical, functional and work outcomes in } \\
\text { spondyloarthritides during real-life } \\
\text { adalimumab treatment in central-eastern }\end{array}$ \\
\hline
\end{tabular}




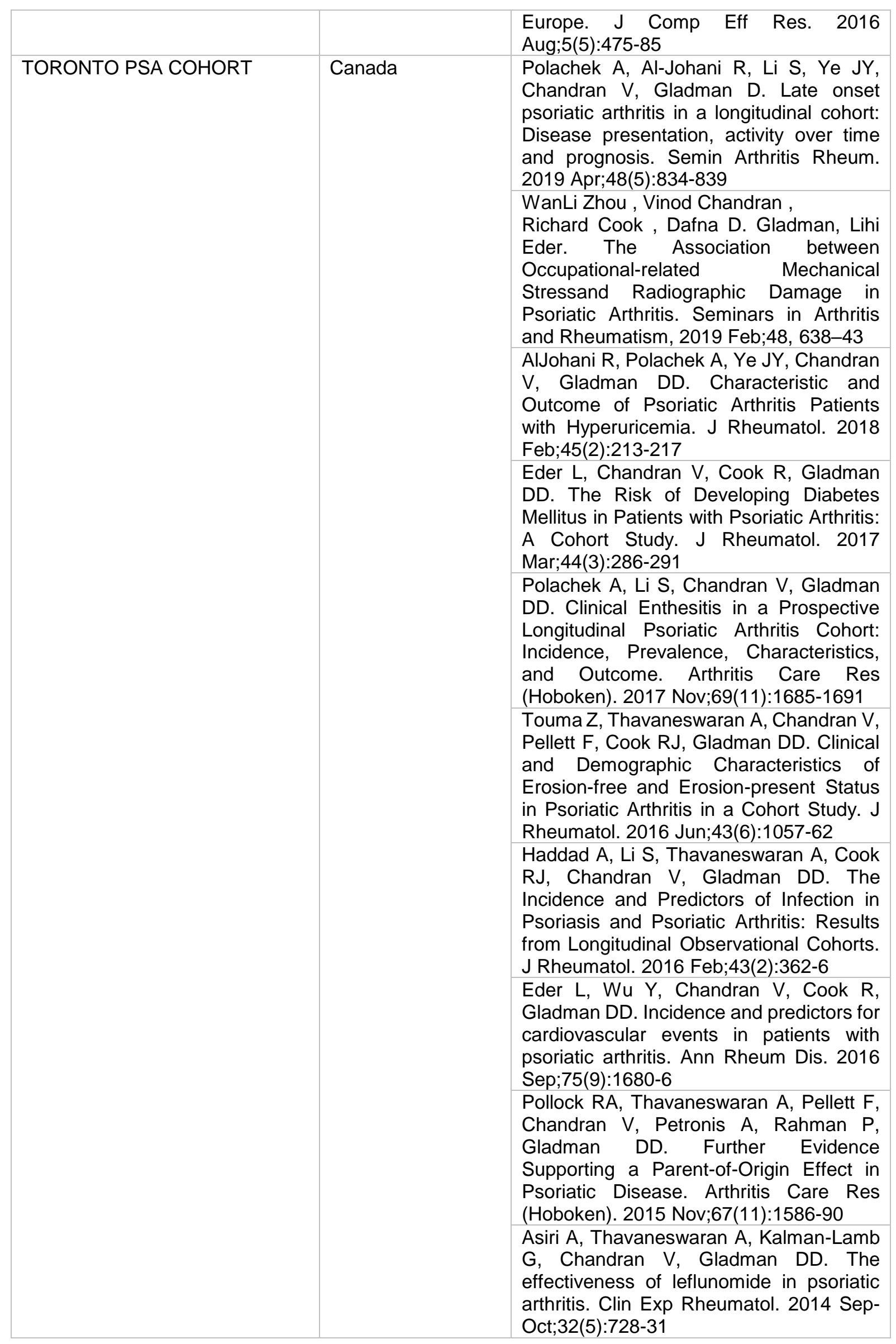




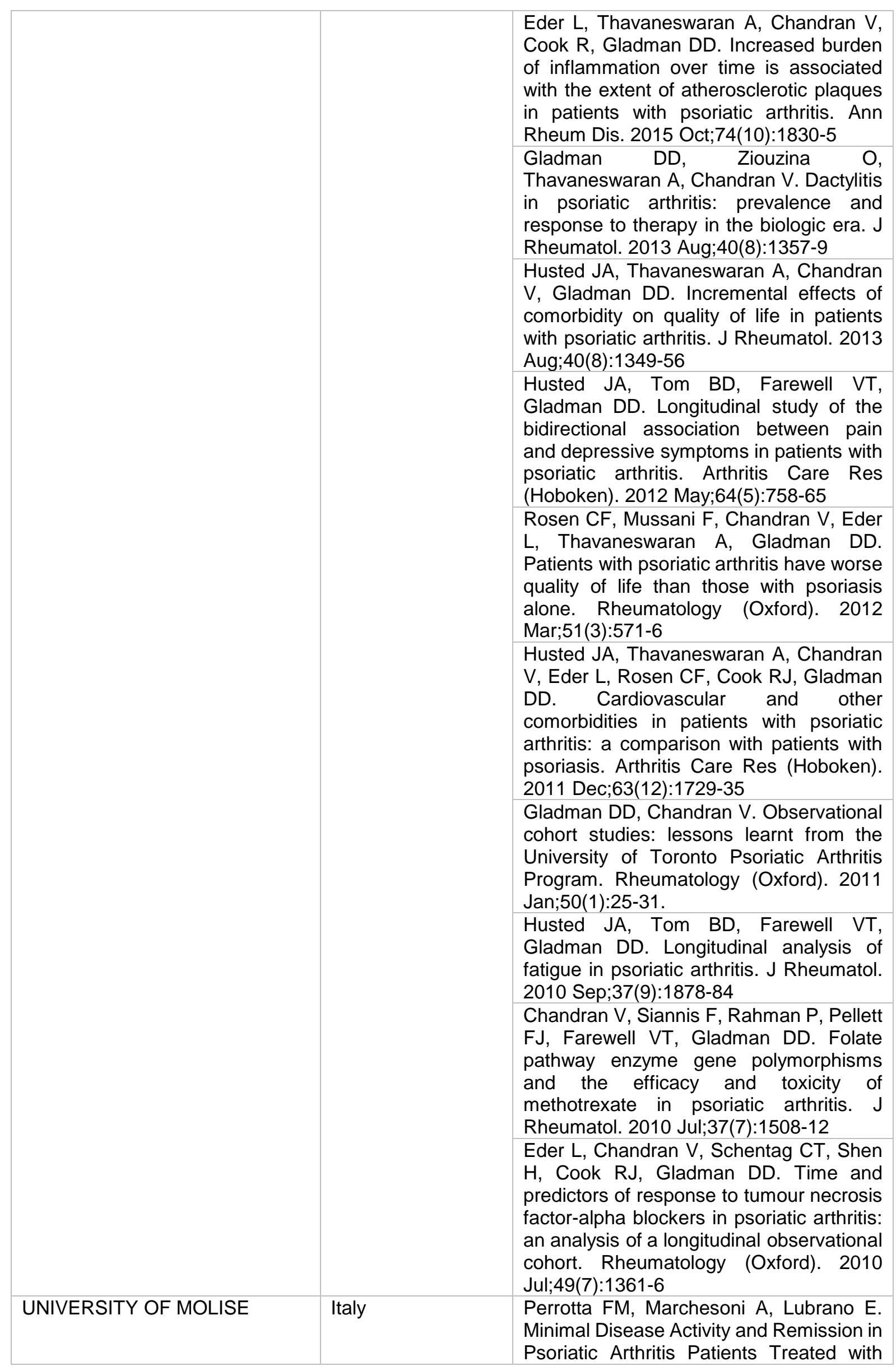




\begin{tabular}{|l|l|}
\hline & Anti-TNF- $\alpha$ Drugs. J Rheumatol. 2016 \\
\hline UTAH COHORT & Feb;43(2):350-5 \\
& Walsh JA, McFadden ML, Morgan MD, \\
& Sawitzke AD, Duffin KC, Krueger GG, \\
& Clegg DO. Work productivity loss and \\
& fatigue in psoriatic arthritis. J Rheumatol. \\
& 2014 Aug;41(8):1670-4 \\
\hline & Walsh JA, Callis Duffin K, Krueger GG, \\
& Clegg DO. Limitations in screening \\
& instruments for psoriatic arthritis: a \\
& comparison of instruments in patients with \\
& psoriasis. J Rheumatol. 2013 \\
& Mar;40(3):287-93 \\
\hline
\end{tabular}


